\title{
Returning home: An evaluation of Hungarian return migration
}

\author{
Gábor LADOS and GÁвor HEGEDÜS ${ }^{1}$
}

\begin{abstract}
This paper deals with the Hungarian return migration process and the importance of identity changes for migration decisions. Outmigration of labour force from Hungary and other East Central European countries has intensified after the EU accession in 2004 and 2007. The possibility of free movement encouraged many Eastern and Central European citizens to leave their country; however, this is not a one-way process. A significant number of migrants returned to the home country with newly acquired skills and other assets. The majority of migration theories evaluate return migration by the role of family, motivations or different kinds of acquired capital, but the importance of identity change is less considered. Our primary aim is to investigate the future migration strategy of Hungarian returnees. The paper is based on national policy analysis and indepth interviews. According to our results, interviewees highlighted the role of work experience and family status. In general, highly skilled returnees met fewer obstacles during their return due to higher flexibility and former employer contracts, but family issues might represent more obstacles during the return. Lower skilled returnees were more dissatisfied with their return, especially those who migrated together with their family members. Hence, the chance for another emigration was higher than in the highly skilled group.
\end{abstract}

Keywords: emigration, return migration, circular migration, migration policies, identity change, Hungary

\section{Introduction}

The importance of migration including return migration is increasing worldwide. Global professionals take part more and more in different migration processes (ConwAy, D. and Potter, R.B. 2009). As part of global trends, millions of people moved to the more developed countries within the European Union after the enlargements in 2004 and 2007 (Nagy, G. 2010; Egedy, T. and Kovács, Z. 2011; Hegedús, G. and Lados, G. 2015).

The countries suffering from emigration are increasingly aware of the negative effects of this phenomenon called "brain drain". More and more specific national policies, initiatives and programmes with different territorial scopes have been established. We use the terms of "remigration policy", "remigration initiative" and "remigration programme" as synonyms, as they are considered such in Hungary. Remigration policy measures were not very successful at the beginning, since re-attracting emigrants is a difficult objective. A reason for such hardship is that remigration policies define the group of returnees in a fairly general way. But some researchers point out individual factors determining the decision of return (VAn Houte, M. and Davids, T. 2008; SinAtTI, G. and Horst, C. 2015), including the effects of different territorial scales (Boros, L. and PáL, V. 2016).

The first main question of our study focuses on the features of return migration policies in Hungary. We analysed most of the Hungarian policies and initiatives previously in a more detailed way (Kovács, Z. et al. 2012; Hegedús, G. and LAdos, G. 2015). In addition, in 2016 we made content analysis of the website "Come Home, Youth" programme aimed explicitly at re-attracting emigrants. Our second main question examines the identity change of Hungarian returnees

\footnotetext{
${ }^{1}$ Department of Economic and Social Geography, University of Szeged, H-6701 Szeged, P.O. Box. 650.

E-mails: ladosg@geo.u-szeged.hu, hegedusg@geo.u-szeged.hu
} 
in the analytical framework of the Cultural Identity Model of Sussman (Sussman, N.M. 2011), with some adaptations.

We conducted 48 semi-structured interviews with Hungarian citizens who returned to Hungary between 2012 and 2015 in order to analyse their identity change. Interviewees were selected by snowball sampling, and we used pseudonyms in our study. Our sample includes both highly-qualified (e.g. researchers, physicians) and less-qualified (e.g. waiters, unskilled workers) returnees. Returnees who took up unskilled jobs in foreign countries as compared to their professional qualifications were also included in the less-qualified group.

The examination of macro- and microlevel factors that are often indistinguishable played an important role for both of our research questions (CASSARINO, J-P. 2004; Sussman, N.M. 2011). We consider individual factors in a narrower sense (e.g. family or friends). In our analysis, the macro-level encompasses basically national or transnational factors (e.g. general economic or income conditions).

\section{The general features of emigration, remigration and change of identity}

According to the literature, research on return migration within the broader phenomenon of migration became significant from the 1970s (Glaser, W.A. and Habers, C.G. 1974; Gmelch, G. 1980; Cassarino, J-P. 2004; VAN Houte, M. and Davids, T. 2008; De HaAs, H. 2010), and as for Hungary, from the late 2000s (LANGER-RÉdeI, M. 2007; KovÁcs, Z. et al. 2012).

National policies supporting return migration can be classified according to various aspects (Lowell, L.B. 2001; VAn Houte, M. and DAvids, T. 2008). Based on these aspects, we developed our own categorisation. According to their objectives, remigration polices were classified as "re-attraction", "reintegration", "re-employment", "networking" (with diaspora members abroad) or "immigration" (which encourages immigration and there- fore prevents "brain drain" - Hegedús, G. and LAdos, G. 2015). In our research, re-migrants are persons older than 15 years old, who returned to their country of birth after having been international migrants in another country (Kovács, Z. et al. 2012; Hegedús, G. and Lados, G. 2015). Theories of return migration focus generally less on the individuals' personality such as their identity and identity changes (SinatTi, G. and Horst, C. 2015). Nevertheless, identity and identity changes can significantly influence the individual's future migration decisions (BERRY J.W. 1997; Van Houte, M. and Davids, T. 2008; Sussman, N.M. 2011).

In relation to return migration, circular migration can also be defined diversely (Wickramasekara, P. 2011; Illés, S. and Kincses, Á. 2012). According to the definition by Wickramasekara, P. (2011), circular migration is a temporary, repeat movement of a population that consists of more than one migration cycle (a migration cycle involves an outmigration phase from the sending country and a remigration phase to the sending country).

The integration into the host culture is not uncomplicated for emigrants. BERRY's acculturation model points out two main challenges for emigrants: how they maintain their native culture and how they adopt the host culture (BERRY, J.W. 1997). BERRY, however, does not examine the case of remigrants (e.g. their "re-acculturation"), but Sussman studies this group and process as well. Sussman's Cultural Identity Model examines the temporal change of cultural "identity" and the cultural "flexibility" of re-migrants from the time before emigration until the period after remigration (SusSMAN, N.M. 2011).

According to Sussman, the adaptation of host cultural values takes places in different ways during the migrants' period abroad. The "Cultural Identity Model" defines four different strategies of identity shift (and groups) of returnees.

The "affirmative" identity shifters maintain their home culture identity while abroad, and they are not so adaptive towards the host 
culture. They feel much better in their native country. The members belonging to the two other types have a lot of stress related to their return. But the features of these two groups are different. Therefore, it is important, that people of the first group (called "subtractive") are not attached firmly to the culture of the host or the native countries either. But they attempt to acquire as many new things as possible while they are abroad.

The second mentioned group, called "additive" is quite similar, except for their relation to the different cultures, which distinguishes them from the "subtractive" group. Additive returnees also insist on keeping their native culture. Nevertheless, they are more open towards new things abroad, and usually adapt to some of them. They still uphold connections with their host country even after their return.

The fourth returnee group within the Cultural Identity Model is called "global" or "intercultural". Its members are able to have more identities simultaneously, and adapt different cultural patterns according to their actual circumstances. This does not imply a kind of mixing of native and host culture elements for them, or establishing a dual (e.g. bicultural) identity. Such returnees consider themselves transnational and cosmopolitan, and they can adapt to the expected social requirements everywhere in the world in a fast and flexible way. They esteem their return as a moderately positive and not a final experience, since they are ready to move abroad again for a shorter or longer time in the future (Sussman, N.M. 2011).

\section{The place of Hungary in the European migration pattern}

The emigration of qualified workforce is a serious problem in Hungary. It is difficult to provide the exact number of Hungarian emigrants, but it has been increasing for the last several years (GöDRI, I. et al. 2014). Therefore, the reasons for emigration and return initiatives that counterbalance the brain drain are worth investigating.
Differences in wage levels among member states of the European Union intensified EastWest European migration flows. Furthermore, it was supported by the liberalisation of the labour markets of old member states and the free movement between EU countries. Source countries and regions suffer from most of the negative effects of emigration, such as a lack of qualified workforce, but migration also puts pressure on the social services and housing market of the host countries (LADOs, G. et al. 2015). Analysing the migration patterns of European regions we can distinguish central, peripheral and internal-peripheral regions (Kovács, Z. et al. 2012). The most developed European regions could be characterised as central regions (e.g. the successful postfordist regions, PÁL, V. and Boros, L. 2010). Conversely, peripheral regions are located mainly in post-socialist countries, southern parts of the Mediterranean and the sparsely populated regions of Scandinavia. The socalled "internal-peripheries" were recorded in the former East Germany, North of France or North of England (Figure 1).

The majority of EU regions suffering most intensely from out-migration are located in post-socialist countries (Kovács, Z. et al. 2012). Millions of East Central Europeans left their home countries during the last few decades (Table 1). Most of them originated from Romania or Poland, while more developed countries such as the Czech Republic and Slovenia were less affected by emigration. However, the out-migration of the labour force has different effects on the home countries. For example, in the less populated Baltic states the share of out-migrants per 10,000 inhabitants is higher than in the Visegrád countries (LAdos, G. et al. 2015).

According to previous research, about 330,000-350,000 Hungarians live in other EU countries. This is only an estimate, because only the age group between 18 and 49 was considered during this research (KAPITÁNY, B. and RoHr, A. 2013). National and international statistical databases cannot provide the exact number of emigrants; however, they show the dynamics of the emigration process 


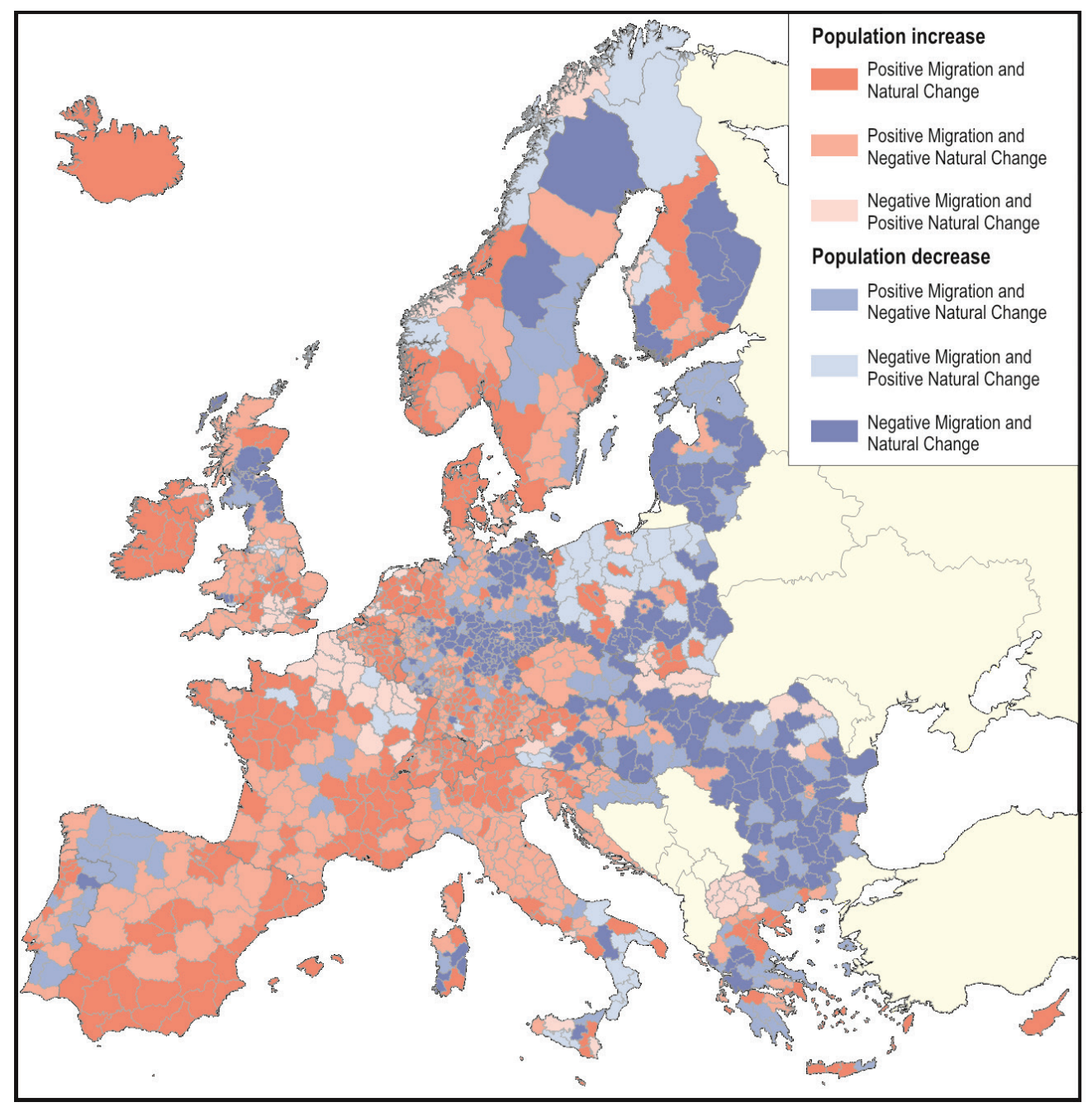

Fig. 1. Population change by main components (2000-2007). Source: Kovács, Z. et al. 2012.

Table 1. The number and rate of East Central European's living in another EU country, 2014

\begin{tabular}{l|c|c}
\hline \multicolumn{1}{c|}{ Country } & Number of emigrants & Emigrants per 10,000 persons \\
\hline Romania & $2,402,792$ & $1,204.6$ \\
Lithuania & 327,641 & $1,113.1$ \\
Latvia & 172,190 & 860.3 \\
Croatia & 292,245 & 688.2 \\
Bulgaria & 420,080 & 579.8 \\
Estonia & 70,166 & 533.2 \\
Poland & $1,968,035$ & 517.7 \\
Slovakia & 191,353 & 353.3 \\
Hungary & 276,710 & 280.1 \\
Slovenia & 34,036 & 165.1 \\
Czech Republic & 92,662 & 88.1 \\
\hline
\end{tabular}

Source: The authors' own calculation based on Eurostat 2015. 
very well (Figure 2). The rate of out-migration from Hungary was three and a half times higher in 2014 than in 2001 (GöDRI, I. 2015).

Initially, after the EU enlargement in 2004 the number of Hungarian emigrants raised slowly. The main host countries for Hungarians did not change essentially, although there were some shifts compared to the period before 2004. In 2015, the most important host country was still Germany. According to Eurostat, 40.7 percent of Hungarian emigrants are currently living in Germany; however, in 2001 this proportion was 59.8 percent. The role of United Kingdom increased most dramatically. In 2001 only 4.7 percent of Hungarian emigrants lived in the country, whereas in 2015 it had grown 23.4 percent. As a historically important destination country, $14.7 \%$ of Hungarian emigrants settled in Austria (HÁrs, Á. et al. 2004; GöDRI I. 2015). It is more difficult to provide the number of Hungarians living outside of Europe. Major non-European destination countries are USA, Canada, Australia, Russia and Israel. According to UN data, 36 percent of Hungarians living abroad moved to these countries. The role of North America is significant; every fourth Hungarian emigrants lives there (GöDRI, I. 2015).
Providing the exact number of returnees is also challenging. Aside from the increasing flows of out-migrants from Hungary, more and more Hungarians are returning. According to available data, there have been more than 10,000 Hungarian returnees in recent years (KincSES, Á. 2014).

When considering their return, the labour market conditions of Hungarian regions play an important role. The rate of return to the previous places of residence was only 30.7 percent. Most Hungarians return to Budapest and its agglomeration, Lake Balaton and its surroundings, and bigger cities are also more attractive than rural peripheral areas (Kincses, Á. 2014).

\section{The study of remigration policies and initiatives in Hungary}

Hungarian remigration initiatives are usually not co-ordinated. Additionally, they focus only on some narrow fields of the return migration (KovÁcs, Z. et al. 2012; Hegedús, G. and Lados, G. 2015). A general and comprehensive national-level policy has yet to be created and implemented in Hungary.

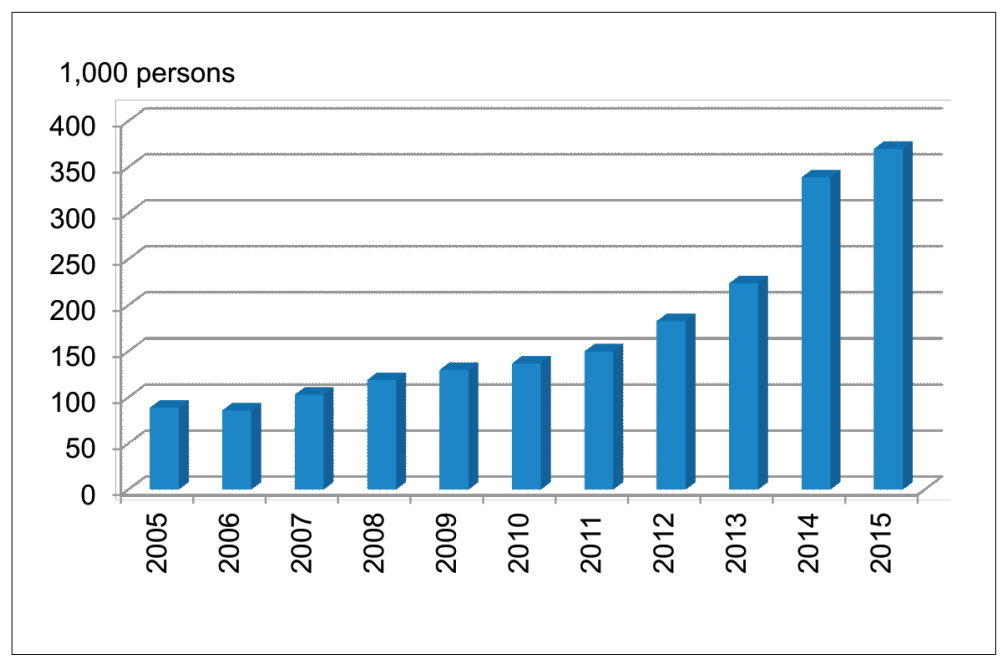

Fig. 2. Hungarians living in other EU countries (2005-2015). Source: Authors' own calculation based on Eurostat 2015. 
The "Project Retour" (2003-2005) was the first Hungarian initiative, which offered networking services and help in returning for well-educated young Hungarians working abroad. After 2011, scholarships were established in different areas of the Hungarian health-care system with the aim of retaining health-care professionals mostly by raising their wages (Hegedús, G. and Lados, G. 2015; Boros, L. and PÁL, V. 2016). Workforce retention was also targeted at by the adoption of a new law on higher education in 2011. According to the law, students have to work in Hungary for the 20 years following their graduation for a time period that equals their government-financed university education. Campaign films realised as part of the "Future of New Generation" government programme were made for the youth in 2012 (Hegedús, G. and Lados, G. 2015).

One of the best-known Hungarian initiatives is the "Momentum" programme, which has functioned since 2009. In the beginning, the main aim of this initiative was to re-attract young talented researchers to Hungary. But so far, the main objective of this initiative has been retention (Hegedús, G. and Lados, G. 2015). Such initiatives are significant in the academic world not only in Hungary, but in other countries, as well (MARTIN, R. and RADU, D. 2012).

The "Come Home" Foundation was established in 2010 as a non-governmental initiative to facilitate the return of Hungarians living abroad who are willing to come home. Supported by the Ministry of Human Capacities, the foundation extended its services in 2013. The "Come Home, Youth" programme was launched also by the Ministry for National Economy in 2015. This complex programme included the "re-attraction", "reemployment" and "retention" types of remigration policies, similar to several other initiatives (e.g. ThAFF in East-Germany, KovÁcs, Z. et al. 2012) in the European Union.

The target groups of the "Come Home, Youth" programme were mostly emigrants with higher education or a profession in great demand in the Hungarian labour market. Emigrants from the United Kingdom alone could participate in the programme [1]. This programme offered many services to returnees (Table 2), but it attracted only a small number of migrants. As a result, in June 2016 the programme was discontinued [2]. Nevertheless, another programme was set to be launched in June 2016, that encourages young Hungarian returnees to become entrepreneurs. It would support returnees who would start a new enterprise in Hungary, since, according to the experiences with "Come Home, Youth", some of the returnees had such plans [3]. The Foundation "Come Home" will continue its activity, as well.

\section{Evaluation of emigration and return migration of Hungarian returnees for different perspectives}

For the purpose of our study, we conducted semi-structured interviews with Hungarian returnees to find out how they personally assess their return. On the one hand, we aimed to analyse the extent of their identity change while abroad. On the other hand, we examined the role of micro and macro factors at three moments: before emigration, while living abroad and after their return.

Only relatively few interviewees could be characterised as affirmative returnees according to Sussman's identity change model (Sussman, N.M. 2011). Those were mainly lower skilled migrants. They did not feel comfortable abroad and came back with some savings, which was spent immediately after their return. Subtractive identity shifters were primarily lower skilled migrants who emigrated with their families. They typically tried to utilise each input abroad, but they managed to acquire new skills only to a limited extent because of their working conditions and their lower language skills. This latter issue also prevented them from improving their language abilities at work because they could not communicate clearly with other immigrant colleagues, or simply they did not need to use the language of their host country, because they only had Hungarian colleagues. 
Table 2. The main services offered by "Come Home, Youth" Programme

\begin{tabular}{|c|c|}
\hline Services offered & Details \\
\hline Introduction of partner firms. & $\begin{array}{l}\text { General information service for returnees about } \\
\text { partner firms registered in the programme. }\end{array}$ \\
\hline $\begin{array}{l}\text { Information about the latest vacancies at partner } \\
\text { firms. }\end{array}$ & $\begin{array}{l}\text { Detailed information on new vacancies at partner } \\
\text { firms registered the programme. }\end{array}$ \\
\hline $\begin{array}{l}\text { Information about: } \\
\text { a) job search assistance, } \\
\text { b) housing allowance, } \\
\text { c) mobility allowance. }\end{array}$ & $\begin{array}{l}\text { a) A single reimbursement of the costs of travelling to } \\
\text { the job interview and back. } \\
\text { b) Supplement on rental prices and general ex- } \\
\text { penses. } \\
\text { c) Housing supplement for taking up a job far away } \\
\text { from the place of residence, mobility supplement } \\
\text { on commuting between residence and workplace } \\
\text { (both for employers and returnees). }\end{array}$ \\
\hline $\begin{array}{l}\text { Information about employment opportunities in } \\
\text { Hungary. }\end{array}$ & Detailed information. \\
\hline $\begin{array}{l}\text { Information on entrepreneurship opportunities in } \\
\text { Hungary. } \\
\text { Assistance for starting up an enterprise. }\end{array}$ & $\begin{array}{l}\text { Elementary entrepreneurship knowledge, e- } \\
\text { learning education, professional advice on making } \\
\text { business plan, mentorship for enterprises. }\end{array}$ \\
\hline Information package about possibilities of return. & $\begin{array}{l}\text { Practical advice (task before leaving the United } \\
\text { Kingdom, the administrative process of homecom- } \\
\text { ing, information needed after returning). }\end{array}$ \\
\hline Mentorship in London and Budapest. & $\begin{array}{l}\text { E.g. preparation of returnees for job interviews } \\
\text { with firm chosen. }\end{array}$ \\
\hline Latest news. & Different news targeting the youth. \\
\hline Success stories. & Some selected individual success stories. \\
\hline
\end{tabular}

Source: The authors' own edition based on "Come Home, Youth Programme. http://www.gyerehazafiatal.hu/ Accessed 13.06.2016.

The integration of subtractive migrants to the host society was hampered by their family ties. They usually stayed close to each other, and spent their free time together or with other Hungarians, while singles were more sociable. They reported several difficulties related to their reintegration. For instance, reintegration to the labour market of the home country was often difficult, as foreign working experiences were not necessarily advantageous. Another significant problem was that they were unable to achieve their goals, their original expectations of their return.

Many returnees mentioned that they had hoped to be able to start a family or have a stress-free life without financial problems after their return, but the majority were disappointed. A returnee quoted one of his friends, also working abroad: "we are working so much here [abroad] (...) and we absolutely do not have better living conditions than those who never left home". He mentioned as an example a former class mate who "has a house, two cars, children, goes to Greece every year for a holiday (...) and we are working like crazy". He had realised that his life in general was not as good as he had thought it would be. He returned home with great expectations, but very soon he changed his mind, when he faced an unexpected situation during the construction of his house: "It was a real slap in the face. Work inspectors came and fined me. At my house! That was outrageous!" (Ferenc, labourer).

For subtractive and additive identity shifters, the most important return motivation was family. On the one hand, subtractive returnees felt unhappy about their return because it was contrary to their initial ambition. "Our children wanted to come back. We did not want to be separated from each other, so we followed them. When they finish secondary school, we [the parents] are sure to go abroad again because I cannot find any suitable job here" (Zoltán, butcher). In view of these negative 
factors, lower skilled people are more likely to leave their home country again; hence, they could be regarded as potential circular migrants (Illés, S. and Kincses, Á. 2012; Martin, R. and RADU, D. 2012).

On the other hand, additive returnees also made some compromises during their return; however, thanks to their better skills, they could seek more opportunities abroad, so they felt more positive about their return. This group of returnees also includes graduates who were employed in lower skilled jobs in the host country. They consider their foreign working experience and their improved language skills as major benefits of their emigration. Furthermore, highly skilled returnees returning with their family were also classified with this group. We found that they also felt more unhappy about their return than their family members because the migration decision was made at the family level: "I would have gladly stayed abroad, but my child did not feel comfortable there. (...) I rather chose my family (...) On my own I would have not returned home. But as for my current workplace, I don't have anything to complain" (Tamás, researcher).

According to the identity change model, the most successful returnees are global identity shifters who changed most during the migration process (Sussman, N.M. 2011). Mainly highly skilled single returnees could be characterised as returnees with a global identity shift. They experienced changes in both their professional and private lives. One of them said: First, I would position myself as a European; second, a Budapester; and third, a Hungarian" (Szabolcs, translator).

Highly skilled returnees did not cut their ties with their former employers, so their reintegration to the Hungarian labour market was smoother than in the case of lower skilled returnees. Further, they could easily utilise their newly acquired skills, such as management and technological know-how, therefore, in most cases their return generated job advancement as well.

During the research we also focused on the importance of micro and macro factors and assessed their role three times during the migra- tion process: before emigration, during the stay abroad and after the return. The fact that micro and macro factors were equally important demonstrates the complexity of migration decisions. Moreover, there was a slight difference among interviewees according to their qualifications. The role of micro factors was more important among highly skilled returnees.

Almost each of them regarded their emigration as a temporary stage of life. As one of them evaluated his emigration: "it was a well calculated, almost obligatory step in my career" (Tamás, researcher).

Another interviewee was looking for a challenge in his life, severed almost all ties with the home country, and moved forward towards the second host country: "I sold my stuff I owned here [in Hungary] and I could have lived only from its interest [abroad]. However, I did not see any perspective in Germany, because I did not own anything, nor did my wife, as we were not born there. It was too comfortable, too perfect. There was no challenge at all" (Márk, entrepreneur).

On the contrary, the role of macro factors was more important for lower skilled returnees, among them higher wages, and the expected savings: "Me and my partner wanted to save as much money for a house as possible. Here, in Hungary it seemed unlikely to reach our goal within some years" (Mária, semi-skilled worker).

The majority of returnees were satisfied with macro factors in the host country and they missed them after their return. Many of them mentioned the advantages of social security (e.g. housing benefits) and the positive effects of change of environment, and numerous possibilities they enjoyed abroad. "We went on excursions a lot. If we did not, we had an invitation to barbeque party (...) Sometimes we just jumped in the car, refuelled it (...) and we drove until it was half empty. Indeed, we did stuff like this all weekend long" (Zoltán, butcher).

Most of the interviewees seemed to have also some very positive memories related to their stay abroad. For instance, learning traditions and culture of the host society was often mentioned. One of the returnees highlighted when he was talking about his colleagues abroad that "politeness is the primary 
behaviour of people in Anglo-Saxon countries. Even so, if they do not like you, they remain polite with you" (József, researcher).

Another returnee confirmed this statement: "It does not matter who you are visiting (...) 'How are you'? (...) Even if you have not met before (...) And they asked it every day, each afternoon they said to me 'See you tomorrow'. It is partly good. And what is going on here? Do not dare to ask a Hungarian because he really tells you in the end" (Zoltán, butcher).

During the return phase the interviewees were motivated by different factors, both on the micro and macro levels. Among microlevel factors, which were more important than macro ones, family had the most conspicuous role. "My elderly parents live here, some of my friends also tie me here, but I had already known before my return that I do not want to live here anymore (...) I just cannot find any job in this region" (Márta, receptionist).

Another returnee came home because his child could not integrate to the host society and did not feel comfortable abroad. Hence, his family decided to return home rather than remain separate from each other. As he assessed his own return: "On a personal level, being here is great, I am together with my family, I think I settled down; I do not have to travel all around the world. But on a professional level this is terrible" (Tamás, researcher).

Nevertheless, family was not the only return motivation. Professional development, especially for highly skilled returnees, was also a significant motivation to return: "In terms of prestige my actual workplace is one of the best in Hungary (...) And I wanted to utilise my foreign working experience in a great place" (Sándor, researcher).

The place of origin also played a crucial role when deciding about the return, but it can be seen as a micro factor rather than a macro factor: "This is an undeveloped region, I know it quite well. But I grew up here, I love all these hills; I almost know every single bush here" (Csaba, labourer).

In conclusion, returnees do not form a homogeneous group. They might go through several identity changes, and micro and macro factors influence them differently. Obstacles during their return might make them consider leaving their home country again.

\section{Conclusions}

Emigration, return migration and circular migration have become inevitable processes of our age. The emigration of professionals often called "brain drain" tends to afflict Hungary and other East Central European countries more intensely, like other semi-peripheral or peripheral countries in the world. In this paper we analysed the most important recent remigration programmes in Hungary. These programmes have various objectives, which can be evaluated positively; however, they have managed to attract only a limited number of return migrants.

We studied the identity change of returning migrants who could be classified into four groups according to Sussman's model. According to our research findings, the role of micro-level factors and identity change should be considered more in the design and implementation of remigration initiatives than previously. It implies on the one hand, that people who are more likely to take part in circular migration or have more stress upon their return should be more assisted by, for example, more detailed information, financial gain or other means. Otherwise their motivations for another emigration increase again. On the other hand, future policies on remigration should also focus more on the skills and social capital of groups maintaining their transnational connections.

Both emigration and circular migration will presumably remain long-term processes in Hungary, a member state of the European Union. Consequently, return migration policies will have more relevance in the future, and an increase the technical and financial support available for returnees seems to be inevitable.

Acknowledgement: This research was realised in the frames of TÁMOP 4.2.4. A/2-11-1-2012-0001 „National Excellence Program - Elaborating and operating an inland student and researcher personal support system". The project was subsidised by the European Union and co-financed by the European Social Fund. 


\section{REFERENCES}

BERRY, J.W. 1997. Immigration, acculturation, and adaptation. Applied Psychology 46. (1): 5-34.

BoROS, L. and PÁL, V. 2016. A magyarországi orvosmigráció néhány jellemzője (Some aspects of emigration of Hungarian doctors). Észak-Magyarországi Stratégiai Füzetek 13. (1): 64-72.

Cassarino, J-P. 2004. Theorising Return Migration: The Conceptual Approach to Return Migrants Revisited. International Journal on Multicultural Societies 6. (2): 253-279.

Conway, D. and PotTer, R.B. 2009. Return Migration of the Next Generations: $21^{\text {st }}$ Century Transnational Mobility. Ashgate, Farnham.

De HaAs, H. 2010. Migration and development: A theoretical perspective. International Migration Review 44. (1): 227-264.

Egedy, T. and Kovács, Z. 2011. Budapest as a destination of migration: the view of transnational creative workers. Hungarian Geographical Bulletin 60. (2): 161-188.

ESPON 2010. The ESPON 2013 Programme DEMIFER - Demographic and migratory flows affecting European regions and cities. Atlas of maps for Draft Final Report. Luxembourg, 37-74.

Glaser, W.A. and Habers, C.G. 1974. The migration and return of professionals. International Migration Review 8. (2): 227-244.

Gmelch, G. 1980. Return migration. American Review of Anthropology 9. 135-159.

GöDRI, I. 2015. Nemzetközi vándorlás (International migration). In Demográfiai portré 2015. Eds.: Monostori, J., ÖRI, P. and SPÉDer, Zs., Budapest, KSH Népességtudományi Kutatóintézet, 187-211.

Gödri, I., Soltész, B. and Bodacz-Nagy, B. 2014. Immigration or emigration country? Migration trends and their socio-economic background in Hungary: A longer-term historical perspective. Working Papers on Population, Family and Welfare 19. Budapest, Hungarian Demographic Research Institute.

HÁrs, A., Simonovits, B. and Sík, E. 2004. The labour market and migration: Threat or opportunity? In Social report 2004. Eds.: KolOsI, T., TóTH, I. Gy. and Vuкоvich, GY., Budapest, TÁRKI, 261-278.

Hegedús, G. and Lados, G. 2015. A remigrációval kapcsolatos európai és magyarországi nemzeti politikák elemzése (Analysis of national remigration policies in European and Hungarian context). ÉszakMagyarországi Stratégiai Füzetek 12. (1): 38-49.

Illés, S. and KincSes, Á. 2012. Hungary as receiving country for circulars. Hungarian Geographical Bulletin 61. (3): 197-218.

KapitánY, B. and RoHr, A. 2013. A Magyarországon állandó lakcímmel rendelkező 18-49 éves magyar állampolgárok mintegy 7,4 százaléka tartózkodik jelenleg tartósan külföldön (7.4 percent of Hungarian citizens between 18-49 years and owning a permanent address in Hungary is permanently residing abroad). Korfa 13. (3): 1-3.
KINCSES, Á. 2014. Nemzetközi migrációs körkép Magyarországról a 2011-es népszámlálási adatok alapján (Review of international migration concerning Hungary according to population census 2011). Területi Statisztika 54. (6): 590-605.

Kovács, Z., Boros, L., Hegedứs, G. and Lados, G. 2012. Returning people to the homeland: Tools and methods supporting remigrants in a European context (Baseline Report). Leipzig, Leibniz-Institut für Länderkunde.

Lados, G., Hegedús, G., Kovícs, Z. and Boros, L. 2015. Oda és vissza - Az elvándorlás hatásainak és a visszavonzás lehetőségeinek értékelése hazánkban (Back and forth - Evaluating effects of emigration and possibilities of return migration in Hungary). In Otthon a Kárpátmedencében. Eds.: Fábián, A. and Bertalan, L., Sopron, Nyugat-magyarországi Egyetemi Kiadó, 115-136.

LANGER-RÉDeI, M. 2007. Mozgásban a világ. A nemzetközi migráció földrajza (The World in motion. Geography of international migration). Budapest, ELTE Eötvös Kiadó.

LowelL, L.B. 2001. Policy Responses to the International Mobility of Skilled Labour. International Migration Papers 45. Geneva, International Labour Office.

Martin, R. and RADU, D. 2012. Return migration: The experience of Eastern Europe. International Migration 50. (6): 109-128.

NAGY, G. 2010. A világgazdaság és a globális munkaerőpiac (The world economy and global labour market). In A globális gazdaság földrajzi dimenziói. Eds.: MÉszáros, R. et al., Budapest, Akadémiai Kiadó, 229-248.

PÁL, V. and Boros, L. 2010. A globális gazdaság ágazati és területi jellemzői (The sectorial and spatial features of global economy). In A globális gazdaság földrajzi dimenziói. Eds.: MészÁRos, R. et al., Budapest, Akadémiai Kiadó, 123-198.

Sinatti, G. and Horst, C. 2015. Migrants as agents of development: Diaspora engagement discourse and practice in Europe. Ethnicities 15. (1): 134-152.

Sussman, N.M. 2011. Return migration and identity. A global phenomenon, a Hong Kong case. Hong Kong, Hong Kong University Press.

VAN Houte, M. and Davids, T. 2008. Development and Return Migration: from policy panacea to migrant perspective sustainability. Third World Quarterly 29. (7): 1411-1429.

WickramaseKara, P. 2011. Circular migration: a triple win or a dead end? Global Union Research

Network. Discussion Paper 15. Geneva, International Labour Office.

[1] http://www.gyerehazafiatal.hu/ ("Come Home, Youth" Programme). Accessed 13.06.2016).

[2] http://www.portfolio.hu/en/economy/hungary scraps_come_home_youth_programme.31428.html

(Hungary scraps "Come Home, Youth" programme, 13.06.2016).

[3] http://www.vg.hu/gazdasag/jon-a-gyere-hazafiatal-program-folytatasa- 471188 .

(The continuation of "Come Home, Youth" Programme, 10.06.2016) 